\title{
Seasonal Variation of Water Quality in Gowain River near Ratargul Swamp Forest, Sylhet, Bangladesh
}

\author{
Md. Nahian', Md. Sirajul Islam*1, Md. Humayun Kabir'1, Tanmoy Roy Tusher' ${ }^{1}$, Nargis \\ Sultana ${ }^{2}$ \\ ${ }^{1}$ Department of Environmental Science and Resource Management, Mawlana Bhashani Science and \\ Technology University, Tangail-1902, Bangladesh \\ ${ }^{2}$ Department of Fisheries Biology and Aquatic Environment, Bangabandhu Sheikh Mujibur Rahman \\ Agricultural University, Gazipur-1706, Bangladesh \\ *Corresponding author (Email: islammstazu@yahoo.com)
}

How to cite this paper: Nahian, M., Islam, M.S., Kabir, M.H., Tusher, T.R. and Sultana, N. (2018). Seasonal Variation of Water Quality in Gowain River near Ratargul swamp forest, Sylhet, Bangladesh. Grassroots Journal of Natural Resources, 1(1): 26-36. Doi:

https://doi.org/10.33002/nr2581.6853.01013

Received: 29 June 2018

Reviewed: 08 July 2018

Provisionally Accepted: 10 July 2018

Revised: 14 July 2018

Finally Accepted: 29 July 2018

Published: 13 August 2018

Copyright (C) 2018 by author(s) and

The Grassroots Institute.

This work is licensed under the Creative Commons Attribution International License (CC BY 4.0).

http://creativecommons.org/licenses/by/4.0/

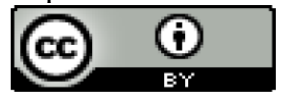

Open Access

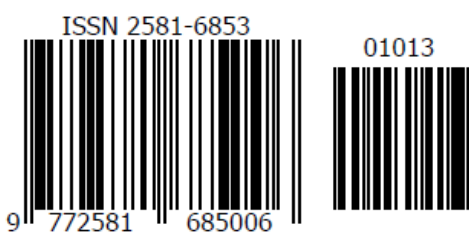

\begin{abstract}
This article is based on a study that was conducted to investigate the physicochemical properties of water in Gowain river at pre-monsoon (February to May), monsoon (June to September) and post-monsoon (October to January) seasons and to determine the relationships between water quality parameters. The water samples were collected from five different sampling stations of Gowain river and analyzed in the laboratory of Department of Environmental Science and Resource Management, Mawlana Bhashani Science and Technology University, Bangladesh. The results also showed that most of the water quality parameters were suitable for aquatic organisms as well as fish. However, runoff from upstream and waste generated from anthropogenic sources could be the main causes of degradation of water quality and aquatic organisms.
\end{abstract}

\section{Keywords}

Water Quality; Seasonal Variation; Gowain River; Ratargul Swamp Forest; Sylhet 


\section{Introduction}

Surface water assets of the Bangladesh are especially basic for keeping alive the distributaries in the delta, for keeping the ecological adjustment of the aggregate district, especially in the estuaries toward the south and at the mouth of the streams, and for keeping up the harsh water environment along the ocean (Islam et al., 2015). Ecosystem changes in the character from west to east contingent upon the accessibility of sweet water from the upland sources (Ahmed and Rahman, 2005). Biodiversity conservation, sustainable economic development and natural resource management of Bangladesh are for the most part profoundly affected by water-its local and occasional accessibility, the nature of surface and groundwater distribution, and its physicochemical properties (Huq, 2008). The surface water monitoring undertaken in the present study provides valuable inputs to the resource managers and surge forecasting.

Water quality generally means the component of water which must be present for optimum growth of aquatic organisms (Islam et al., 2014). The determinant of good growth of biota in a water body includes dissolved oxygen, hardness, turbidity, alkalinity, nutrients, temperature, etc. In most of the water bodies, various chemical parameters occur in low concentration. This concentration level increases due to human activities and lack of environmental regulation (Ehiagbonare and Ogunrinde, 2010). Assessment of water quality and monitoring of any region is an important aspect of sustainability, because rivers, lakes and manmade reservoirs are used for water supply to domestic, industrial, agricultural and fish culture (Joseph, 2010). Water, the most important natural resource in the world, has the unique property of dissolving and carrying in suspension a huge variety of chemicals and hence water can easily become contaminated. Almost all water required for aquaculture in the world is obtained from surface water sources, such as rivers, reservoirs, lakes and canals (Jonnalagada and Mhere, 2001). Plankton abundance depends on the physico-chemical characteristics of the water body. The maximum productivity may be obtained when the physical and chemical parameters are at the optimum level. Therefore, water quality has paramount importance in ecosystem productivity and their sustainable use (Rakiba and Ferdusi, 2013).

Ratargul swamp forest is a freshwater swamp forest located in Gowain river, Fatehpur union, Gowainghat upazila, Sylhet, Bangladesh. It is the only swamp forest located in Bangladesh. This forest is known as Amazon of Bangla and has an area of 3325.61 acre (Chowdhury, 2004). Gowain river is known as the lifeline of Ratargul swamp forest and it inundates the whole forest during monsoon. This river originates from mountain ranges of Meghalaya (India) and flows through the forest. Gowain river water is one of the major sources of nutrients for Ratargul swamp forest (Islam et al., 2016a). At present, the water quality of Gowain river has deteriorated considerably. Some major factors affecting the water quality of Gowain river are grouped into three categories such as manmade factors, environmental factors and policy issues. Now a day's uncontrolled fishing and improper management of tourism are among the main factors responsible for degrading the water quality. Disorganized stone collection, hilly water from upstream and navigation are also the main factors for affecting water quality. Among environmental factors are the reduction of open water depth along with declining rainfall and increasing temperature (Islam et al., 2016b). Thus, the present study was conducted to assess the status of seasonal variability of physico-chemical parameters of water and their relationships between different water quality parameters of the Gowain river. This assessment will trigger the need to enforce the existing water policy, water uses, management implementation plans, antidegradation statement in order to manage the water quality of the Gowain river. 


\section{Materials and Methods}

Study area: The study area was located in the Ratargul swam forest near Gowain river at Gowainghat upazila, Sylhet, Bangladesh (Figure 1). The study area was divided into 5 sampling stations which were denoted as St-1, St-2, St-3, St-4and St-5. The evergreen Ratargul swamp forest is situated alongside the river Gowain and the forest is submerged under 6.09 to $9.10 \mathrm{~m}$ water in the rainy season because excessive water from India enters into the lake through Gowain river. For the rest of the year, the water level remains about $3.05 \mathrm{~m}$ deep (Choudhury et al., 2004).

Sample collection: Water samples were collected from 5 sampling stations for physico-chemical analysis during the period from October 2016 to September 2017. The sampling period were identified as pre-monsoon (February to May), monsoon (June to September) and post-monsoon (October to January) season. Samples were collected from each sampling station into $1000 \mathrm{ml}$ plastic bottles with the help of double stoppers. First, the bottles were cleaned and washed with detergent solution and treated with $5 \%$ nitric acid $\left(\mathrm{HNO}_{3}\right)$ over night. Before the sampling the bottles were properly cleaned and finally rinsed with de-ionized water and were dried. After sampling the bottles were screwed and marked with the respective identification number.

Water analysis: The water quality was analyzed in the laboratory of the Department of Environmental Science and Resource Management (ESRM), Mawlana Bhashani Science and Technology University. Water transparency was determined by Secchi Disc method, whereas the temperature and $\mathrm{pH}$ were determined by the thermometer and digital $\mathrm{pH}$ meter (Model: $\mathrm{pH}$ Scan WP 1,2; Malaysia), respectively. Buffer solution containing $\mathrm{pH} 7.0$ was used to calibrate the digital $\mathrm{pH}$ meter. Digital EC and TDS meter (Model: HM digital, Germany) was used to determine electric conductivity (EC) and total dissolve solids (TDS), respectively. The dissolve oxygen (DO) was determined by digital DO meter (Model: D.46974, Taiwan) while sodium thiosulphate $(0.025 \mathrm{~N})$ was used as a reagent. The biological oxygen demand (BOD) was measured by two steps, and initial $\mathrm{BOD}\left(\mathrm{BOD}_{1}\right)$ was measured immediately after sample collection and after 5 days $\mathrm{BOD}\left(\mathrm{BOD}_{5}\right)$ was measured by incubation in the dark conditions at $20^{\circ} \mathrm{C}$ for 5 days. Thereafter the total $\mathrm{BOD}\left(\mathrm{BOD}_{1}-\mathrm{BOD}_{5}\right)$ was measured in accordance of the methods suggested by Trivedy and Goel (1984) and Huq and Alam (2005). Alkalinity was determined by titration method with $0.1 \mathrm{~N} \mathrm{HCl}$ after addition of 2-3 drops of methyl-orange indicator. The ethylene diamine tetra acetic acid (EDTA) method was used to determine the hardness of water whereas Eriochrome Black $\mathrm{T}$ was used as indicator titration with EDTA solution.

Statistical analysis: The collected data were compiled and tabulated in proper form and were subjected to statistical analysis. The Microsoft Office Excel and SPSS 22.00 software were used to present and interpret the collected data. The results of the study were presented in charts and tabular forms.

\section{Results and Discussion}

\section{Transparency}

During the pre-monsoon season, highest transparency was $13.19 \mathrm{~cm}$ at St-5 whereas the lowest was found $11.50 \mathrm{~cm}$ at St-1. In the monsoon season, the highest $(4.17 \mathrm{~cm})$ and lowest $(3.06 \mathrm{~cm})$ were found at St-3 and St-5, respectively. At the post-monsoon season, highest and lowest

Md. Nahian, Md. Sirajul Islam, Md. Humayun Kabir, Tanmoy Roy Tusher, Nargis Sultana 28 
transparency were found at $\mathrm{St}-1(6.20 \mathrm{~cm})$ and $\mathrm{St}-3(5.60 \mathrm{~cm})$, respectively. The mean transparency was $12.55 \pm 0.64,3.52 \pm 0.53$ and $5.92 \pm 0.24 \mathrm{~cm}$ in pre-monsoon, monsoon and postmonsoon season, respectively (Table 1). The transparency of fresh water is 35.00 to $45.00 \mathrm{~cm}$, which is suitable for aquatic environment (Hossain et al., 2011). So, the transparency of Gowain river water was much below the suitable range. It might be due to the increased level of suspended matter that can be caused by an increased sediment discharge from the river into the water, affecting the lives of many aquatic communities.

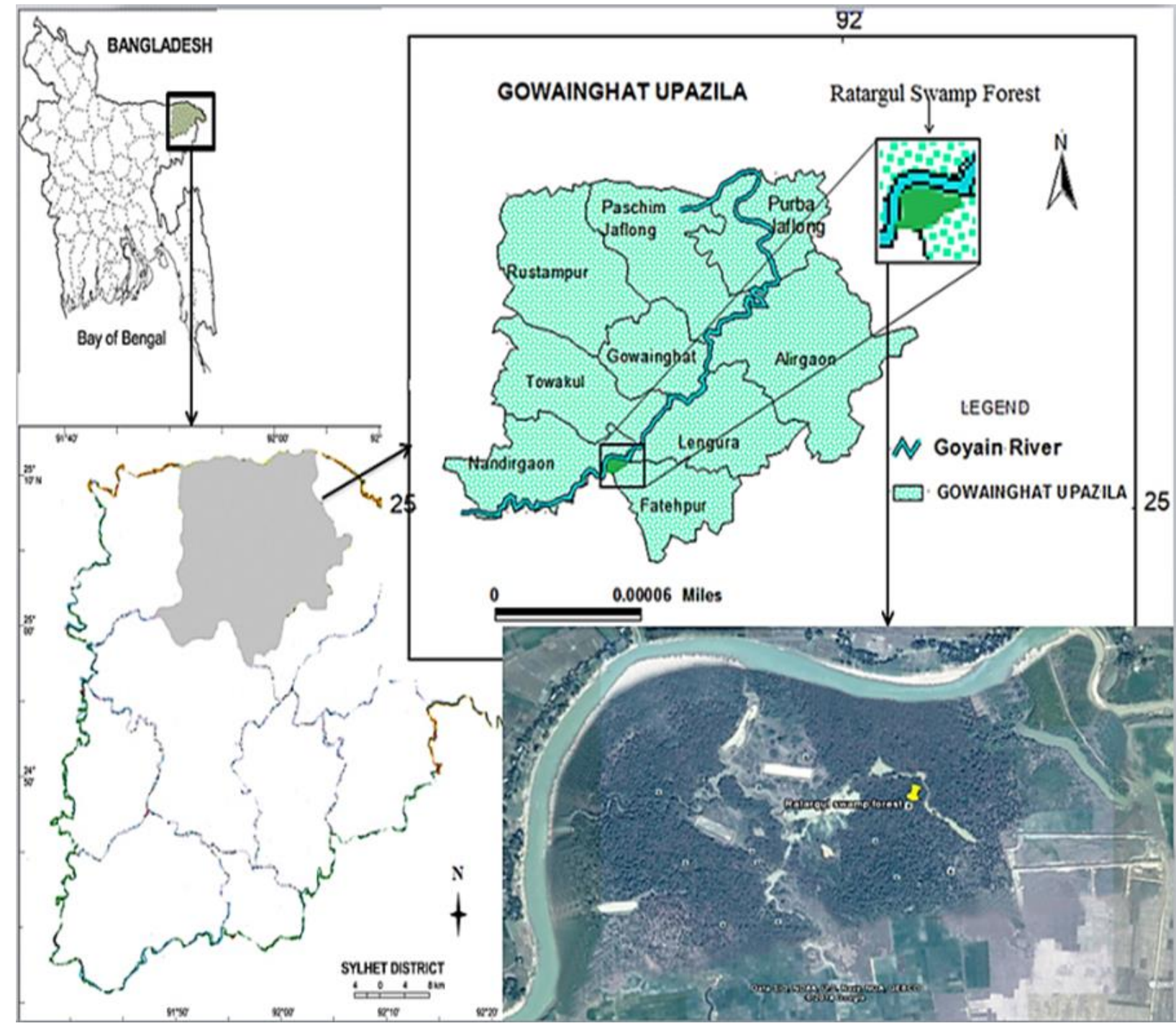

Figure 1. Map showing the study area at Ratargul swam forest near Gowain river area in Sylhet

\section{Temperature}

The highest temperature of water was $27.5^{\circ} \mathrm{C}$ at $\mathrm{St}-2$ whereas the lowest was $27.0^{\circ} \mathrm{C}$ at $\mathrm{St}-4$, respectively, in pre-monsoon season. In the monsoon season, highest and lowest temperature was found 38.3 and $37.2^{\circ} \mathrm{C}$ at St-4 and St-3, respectively. Moreover, in the post-monsoon season, highest and lowest temperature was found at St-4 $\left(26.5^{\circ} \mathrm{C}\right)$ and St $-1\left(24.1^{\circ} \mathrm{C}\right)$, respectively (Table 1). Among the three different seasons, highest temperature was found in monsoon season followed by pre-monsoon and post-monsoon seasons in the all sampling stations (Figure 2). Mean water temperature in pre-monsoon, monsoon and post-monsoon season was 29.22 \pm 0.19 , 
$37.82 \pm 0.45$ and $25.16 \pm 0.86^{\circ} \mathrm{C}$, respectively (Table 1 ), whereas the standard limit of temperature is 20 to $30^{\circ} \mathrm{C}$ (EQS, 1997). Results of the study depicted that water temperature apart from monsoon season was suitable for aquatic biodiversity; this might be due to the weather variability in monsoon season. The temperature of the different sampling points of Hakaluki haor ranged from 26.2 to $33.2^{\circ} \mathrm{C}$ (Islam et al., 2017) those were similar to the present study.

\section{Electrical Conductivity (EC)}

The EC was found highest $(78.35 \mu \mathrm{S} / \mathrm{cm})$ at St-1 and lowest $(74.05 \mu \mathrm{S} / \mathrm{cm})$ at St-4 in premonsoon season, while the highest $(63.10 \mu \mathrm{S} / \mathrm{cm})$ and lowest $(60.80 \mu \mathrm{S} / \mathrm{cm})$ was found at St-2 and St-5, respectively in monsoon season. In post-monsoon, highest and lowest EC was found at St-2 $(87.30 \mu \mathrm{S} / \mathrm{cm})$ and St-5 $(83.20 \mu \mathrm{S} / \mathrm{cm})$, respectively. Mean EC contents were $75.76 \pm 1.58$, $61.90 \pm 0.97$ and $84.26 \pm 1.77 \mu \mathrm{S} / \mathrm{cm}$ in pre-monsoon, monsoon and post-monsoon season, respectively (Table 1). For inland surface water EC contents 800 to $1000 \mu \mathrm{S} / \mathrm{cm}$ is suitable for aquatic environment (ECR, 1997) and the EC contents of Gowain river was very lower than the standard. It might be the absence of dissolution of carbonate minerals, and discharge of waste water, agricultural and urban runoff. The EC contents of Turag river water were ranged from 691 to 822,618 to 1334 and 155 to $276 \mu \mathrm{S} / \mathrm{cm}$ in post monsoon, pre-monsoon and monsoon season, respectively, and in the monsoon season, the flow of the river increases which may cause the dilution of the salinity of the water, while in dry season, the flow of the river decreases which results in increase of EC (Meghla et al., 2013).

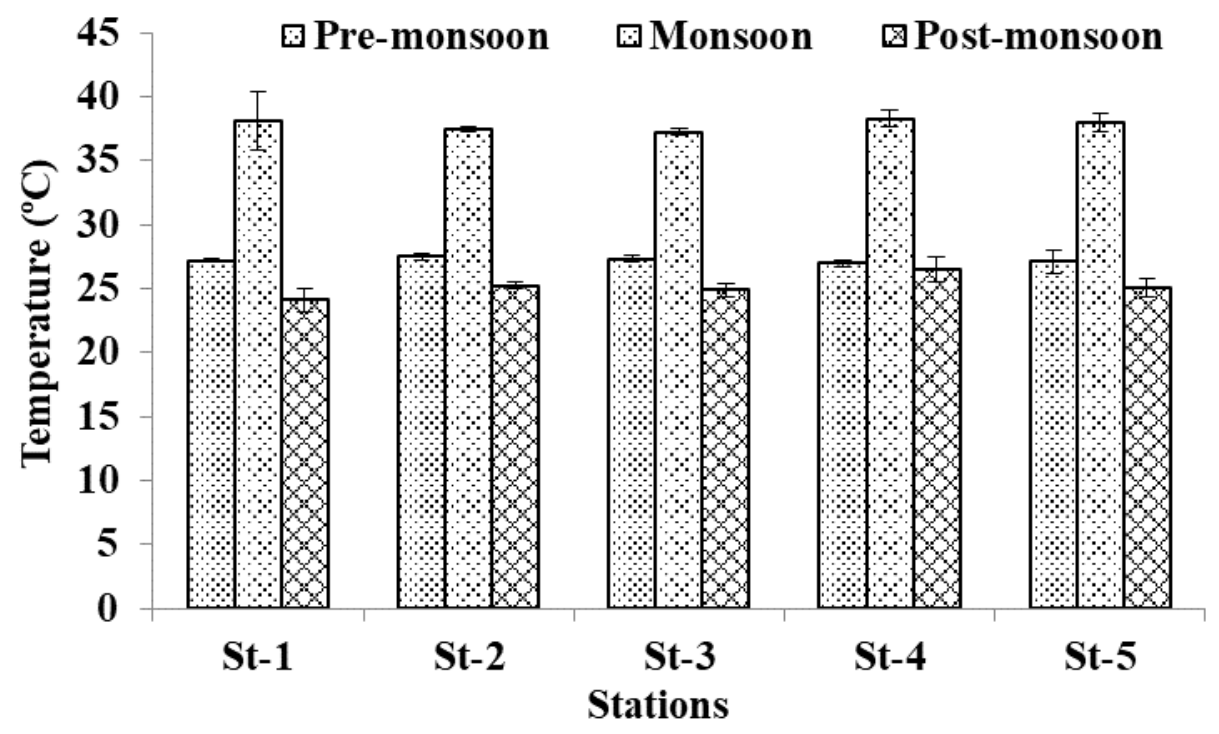

Figure 2. Temperature fluctuations in Gowain river water at different stations

\section{Total Dissolved Solid (TDS)}

The highest and lowest TDS was found at St-4 (41.00 ppm) and St-2 (39.37 ppm) in premonsoon season, respectively. In the monsoon season, highest and lowest TDS was found at St-1 (36.25 ppm) and St-2 (31.05 ppm), respectively whereas in post-monsoon season the highest and lowest TDS was found at St-3 (46.40 ppm) and St-5 (43.00 ppm), respectively. Mean TDS contents were found $39.94 \pm 0.70,33.89 \pm 2.25$ and $44.42 \pm 1.35 \mathrm{ppm}$ in pre-monsoon, monsoon and post-monsoon season, respectively (Table 1). The standard level of TDS for aquatic environment or fisheries is $500.00 \mathrm{ppm}(\mathrm{EQS}, 1997)$ and the results depict that river water had low TDS level. A constant level of minerals in the water is necessary for aquatic life; changes in the amounts of dissolved solids can be harmful because the density of total dissolved solids determines the flow 
of water in and out of an organism's cells. Concentrations that are too high or too low may limit the growth and may lead to the death of many fish or reefs (Weber-Scannell and Duffy, 2007). A comparable observation was done by Islam et al. (2014), where the mean TDS contents of the Padma river water were found 155, 125 and 169 ppm during pre-monsoon, monsoon and postmonsoon, respectively.

Table 1. Physico-chemical water quality parameters of the Gowain river (ranges of parameters are in parentheses)

\begin{tabular}{|c|c|c|c|c|}
\hline \multirow[t]{2}{*}{ Parameter } & \multicolumn{3}{|c|}{ Season $($ Mean $\pm S D, N=20)$} & \multirow[t]{2}{*}{ Standard } \\
\hline & Pre-monsoon & Monsoon & Post-monsoon & \\
\hline \multirow[t]{2}{*}{ Transp. (cm) } & $12.55 \pm 0.64$ & $3.52 \pm 0.53$ & $5.92 \pm 0.24$ & 35.00 to 45.00 \\
\hline & (11.50 to 13.19$)$ & (3.06 to 4.17$)$ & $(5.60$ to 6.20$)$ & (Hossain et al., 2011) \\
\hline \multirow[t]{2}{*}{ Temp. $\left({ }^{0} \mathrm{C}\right)$} & $29.22 \pm 0.19$ & $37.82 \pm 0.45$ & $25.16 \pm 0.86$ & 20.0 to 30.0 \\
\hline & (27.0 to 27.5$)$ & (37.2 to 38.3$)$ & (24.1 to 26.5$)$ & (EQS, 1997) \\
\hline \multirow[t]{2}{*}{$\mathrm{EC}(\mu \mathrm{S} / \mathrm{cm})$} & $75.76 \pm 1.58$ & $61.90 \pm 0.97$ & $84.26 \pm 1.77$ & 800.00 to 1000.00 \\
\hline & (74.05 to 78.35$)$ & $(60.80$ to 63.10$)$ & (83.20 to 87.30$)$ & (ECR, 1997) \\
\hline \multirow[t]{2}{*}{ TDS (ppm) } & $39.94 \pm 0.70$ & $33.89 \pm 2.25$ & $44.42 \pm 1.35$ & 500.00 \\
\hline & (39.37 to 41.00$)$ & (31.05 to 36.25$)$ & (43.00 to 46.40$)$ & (EQS, 1997) \\
\hline \multirow[t]{2}{*}{$\mathrm{pH}$} & $8.14 \pm 0.08$ & $7.76 \pm 0.1$ & $7.44 \pm 0.09$ & 6.50 to 8.50 \\
\hline & $(8.03$ to 8.22$)$ & (7.61 to 7.92$)$ & (7.32 to 7.48$)$ & (EQS, 1997) \\
\hline \multirow[t]{2}{*}{$\mathrm{DO}(\mathrm{ppm})$} & $4.86 \pm 0.5$ & $5.18 \pm 0.53$ & $4.42 \pm 0.38$ & $>5.00$ \\
\hline & $(4.01$ to 5.50$)$ & $(4.60$ to 4.60$)$ & $(4.10$ to 5.10$)$ & $(\mathrm{ECR}, 1997)$ \\
\hline \multirow[t]{2}{*}{$\mathrm{BOD}(\mathrm{ppm})$} & $1.19 \pm 0.10$ & $1.53 \pm 0.24$ & $2.18 \pm 0.14$ & $<6.0$ \\
\hline & (1.01 to 1.30$)$ & (1.10 to 1.72$)$ & (2.02 to 2.37$)$ & $(\mathrm{ECR}, 1997)$ \\
\hline \multirow{3}{*}{$\begin{array}{l}\text { Hardness } \\
(\mathrm{ppm})\end{array}$} & $131.78 \pm 5.85$ & $87.67 \pm 11.78$ & $107.21 \pm 16.35$ & 123.0 \\
\hline & (124.12 to & (73.74 to & (84.90 to & (Huq and Alam, \\
\hline & 140.10) & 103.88) & 124.03) & 2005) \\
\hline \multirow{3}{*}{$\begin{array}{l}\text { Alkalinity } \\
(\mathrm{ppm})\end{array}$} & $279.30 \pm 7.64$ & $163.95 \pm 6.05$ & $188.16 \pm 6.15$ & $>100.0$ \\
\hline & (268.15 to & (159.44 to & (220.48 to & (Rahman, 1992) \\
\hline & $286.52)$ & $171.78)$ & 236.19) & \\
\hline
\end{tabular}

\section{pH}

Average $\mathrm{pH}$ of the study area was alkaline. In the pre-monsoon season, the highest (8.22) and lowest (8.03) $\mathrm{pH}$ were found at St-3 and St-5, respectively. In the monsoon season, $\mathrm{pH}$ was highest and lowest at St-1 (7.92) and St-2 (7.61), respectively, while in post-monsoon season, highest and lowest was found at St-1 (7.48) and St-4 (7.32), respectively (Figure 3). Mean pH was found $8.14 \pm 0.08,7.76 \pm 0.1$ and $7.44 \pm 0.09$ in pre-monsoon, monsoon and post-monsoon, respectively (Table 1). The standard limits of $\mathrm{pH}$ for inland surface water is 6.5 to 8.5 (EQS, 1997) and the study revealed that the $\mathrm{pH}$ values of all sampling stations were within the standard limit. The average $\mathrm{pH}$ in wet and dry seasons was found 7.73 and 8.03 , respectively, in the Tista river (Islam et al., 2015) which is more or less parallel to the present study.

\section{Dissolved Oxygen (DO)}

The highest and lowest DO level in pre-monsoon season was $5.50 \mathrm{ppm}$ at St-4 and $4.01 \mathrm{ppm}$ at St-2, respectively. In monsoon season, the highest and lowest was $5.73 \mathrm{ppm}$ at St-4 and $4.60 \mathrm{ppm}$ at St-2, respectively. At the post-monsoon season, the highest and lowest DO was found 5.10 and $4.10 \mathrm{ppm}$ at St-4 and St-2, respectively (Figure 4). The mean DO level in pre-monsoon, monsoon and post-monsoon season were $4.86 \pm 0.5,5.18 \pm 0.53$ and $4.42 \pm 0.38 \mathrm{ppm}$, respectively (Table 1 ),

Md. Nahian, Md. Sirajul Islam, Md. Humayun Kabir, Tanmoy Roy Tusher, Nargis Sultana 
and the standard level of DO for aquatic organism is $>5.0 \mathrm{ppm}$ (ECR, 1997). Results of the study depicted that DO level of river water was slightly lower, which may affect the aquatic organisms. The DO level varied from 3.5 to 4.9 and 1.9 to $2.8 \mathrm{ppm}$ in wet and dry season, respectively in Bangshi river (Rehnuma et al., 2016), which was almost similar to the present study. Low DO primarily results from excessive algae growth caused by phosphorus and nitrogen. Die-off and decomposition of submerged plants contribute to low DO and this process is called as Carbonaceous Biochemical Oxygen Demand (CBOD). Sources of nitrogen and phosphorus include discharges from cropland water runoff and natural decay of vegetation. These pollutants from point and nonpoint sources into a river segment add to its CBOD loadings, creating an oxygen demand that may depress DO below acceptable concentrations. This may not occur locally, but instead happens farther downstream in pools where the current slows and algae grow (MPCA, 2009).

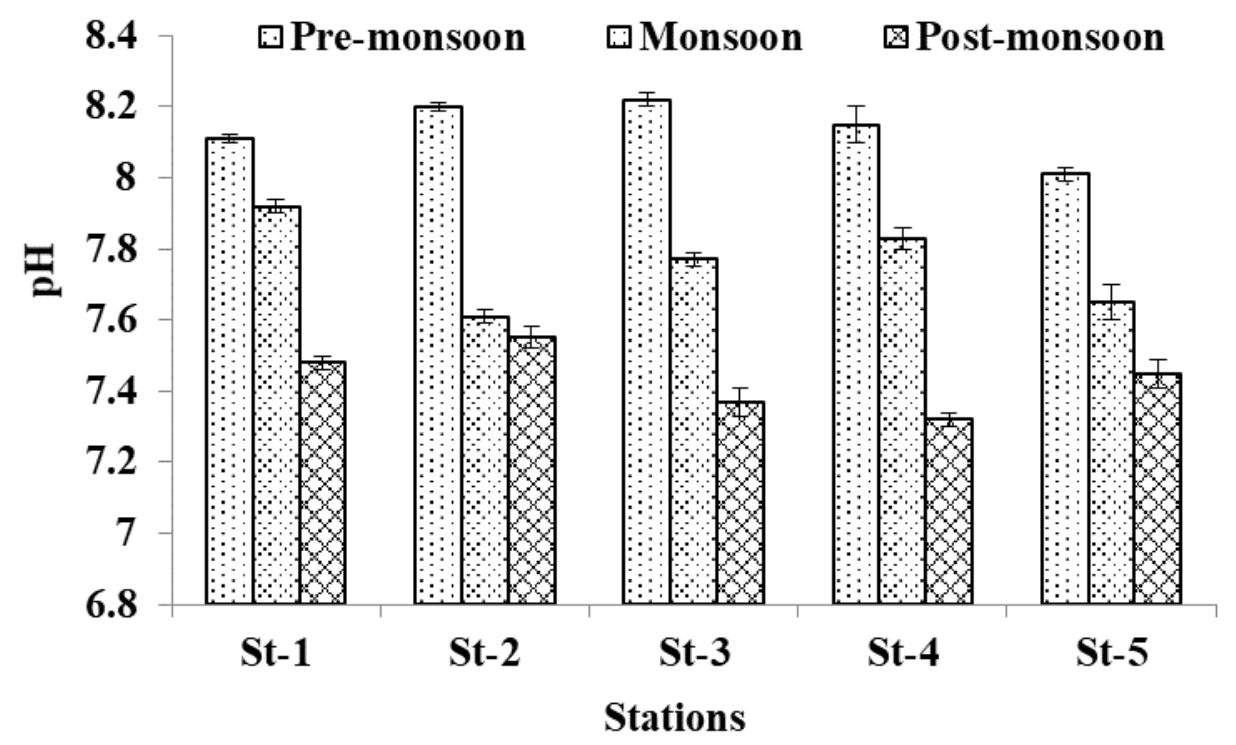

Figure 3. Variation of $\mathrm{pH}$ in the Gowain river water in different stations

\section{Biological Oxygen Demand (BOD)}

At the pre-monsoon season, highest and lowest BOD was found at St-1 (1.30 ppm) and St-2 (1.01 $\mathrm{ppm})$, respectively, whereas in monsoon, highest and lowest BOD was found at St-1 (1.72 ppm) and St-2 (1.10 ppm), respectively. During the post-monsoon season, highest $(2.37 \mathrm{ppm})$ and lowest $(2.02 \mathrm{ppm}) \mathrm{BOD}$ were found at St-4 and St-2, respectively (Figure 5). Mean BOD levels were found $1.19 \pm 0.10,1.53 \pm 0.24$ and $2.18 \pm 0.14 \mathrm{ppm}$ in pre-monsoon, monsoon and post-monsoon, respectively (Table 1). The mean BOD content of the Padma river water was found 1.76, 2.35 and $3.21 \mathrm{mg} / \mathrm{l}$ over the pre-monsoon, monsoon and post-monsoon, respectively, which were likely suitable for fish production (Islam et al., 2014) but closely parallel to the present study.

\section{Total Hardness}

The highest and lowest hardness in pre-monsoon season was $140.10 \mathrm{ppm}$ at St-5 and $124.12 \mathrm{ppm}$ at St-2, respectively. At the monsoon season, highest and lowest hardness were found 103.88 ppm at St-4 and 73.74 ppm at St-5, respectively; whereas during the post-monsoon season, highest $(124.03 \mathrm{ppm})$ and lowest $(84.90 \mathrm{ppm})$ were found at St-1 and St-5, respectively. Mean hardness contents in pre-monsoon, monsoon and post-monsoon season were found 131.78 \pm 5.85 , $87.67 \pm 11.78$ and 107.21 $\pm 16.35 \mathrm{ppm}$ (Table 1). According to Huq and Alam (2005), the optimum 
hardness for aquatic organism is $123 \mathrm{ppm}$, and this study revealed that hardness contents were more or less suitable for fisheries. The average hardness in Tista river water of wet and dry seasons was found 98.48 and 102.46 ppm, respectively (Islam et al., 2015), which is closely analogous to the present investigation.

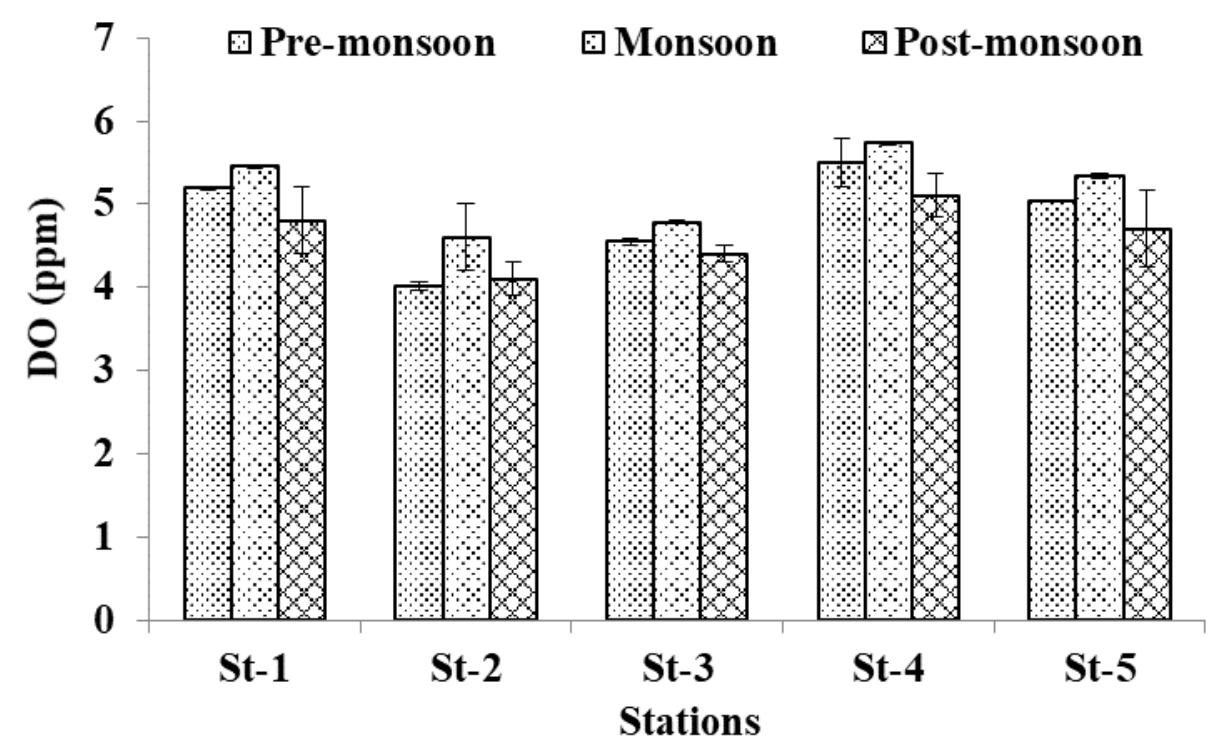

Figure 4. Seasonal variation of DO level in different stations of Gowain river

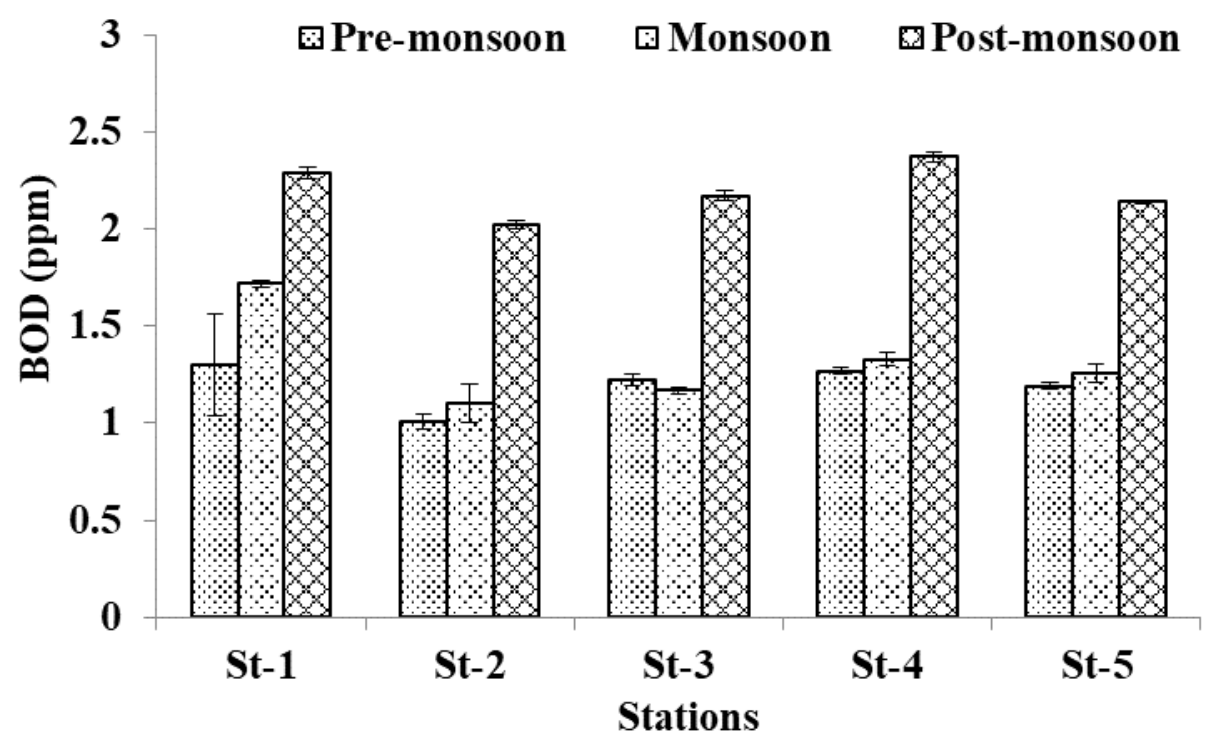

Figure 5. Seasonal variation of BOD level in different stations of Gowain river

\begin{abstract}
Alkalinity
The highest and lowest alkalinity was found 286.52 and 268.15 ppm at St-1 and St-4 in premonsoon season, respectively; while the highest and lowest was 171.78 and 159.44 ppm at St-2 and St-1, respectively. However, in the post-monsoon season, alkalinity was highest (236.19 ppm) and lowest (220.48 ppm) in St-5 and St-2, respectively. Moreover, the mean alkalinity was $279.30 \pm 7.64,163.95 \pm 6.05$ and $188.16 \pm 6.15 \mathrm{ppm}$ in pre-monsoon, monsoon and post-monsoon season, respectively (Table 1). According to Rahman (1992), standard value of alkalinity is $>100$ ppm for fresh water and most of the water samples. Mobin et al. (2014) determined the minimum
\end{abstract}


alkalinity $109.98 \mathrm{ppm}$ at Ashulia in monsoon season and maximum $411.10 \mathrm{ppm}$ at Abdullahpur in pre-monsoon season of the Turag river.

Table 2. Pearson's correlation matrix of water quality parameters

\begin{tabular}{|c|c|c|c|c|c|c|c|c|}
\hline Parameter & Transparency & Hardness & $B O D$ & $T D S$ & $E C$ & $D O$ & $p H$ & Temp. \\
\hline Transparency & 1 & & & & & & & \\
\hline Hardness & $0.849^{* * *}$ & 1 & & & & & & \\
\hline BOD & -0.358 & -1.73 & 1 & & & & & \\
\hline TDS & 0.310 & 0.373 & $-729^{* *}$ & 1 & & & & \\
\hline $\mathrm{EC}$ & 0.375 & 0.471 & $0.667^{* *}$ & $0.929^{* *}$ & 1 & & & \\
\hline DO & -0.200 & -0.205 & -0.125 & -0.378 & -0.504 & 1 & & \\
\hline $\mathrm{pH}$ & $0.702^{* *}$ & 0.509 & $-778^{* *}$ & -0.331 & $\overline{-}^{-} .903^{* *}$ & 0.146 & 1 & \\
\hline Temperature & $-0.586^{*}$ & $-6.41^{*}$ & -0.497 & $-903^{* *}$ & ${ }^{-} .960^{* *}$ & 0.446 & 0.096 & 1 \\
\hline
\end{tabular}

${ }^{* *}$ Correlation is significant at the 0.01 level

*Correlation is significant at the 0.05 level

This study shows that the parameters are correlated linearly to a great extent. Table 2 shows the correlation matrix of water samples indicating negative correlation between transparency and DO ( $\mathrm{r}$ $=-2.00)$, transparency and BOD $(r=-0.358)$, transparency and temperature $\left(r=-0.586^{*}\right)$, BOD and hardness $(r=-1.73)$, DO and hardness $(r=-0.205)$, temperature and hardness $\left(r=-6.41^{*}\right)$, TDS and BOD $\left(r=-0.729^{* *}\right)$, BOD and DO $(r=-0.125)$, BOD and $\mathrm{pH}\left(\mathrm{r}=-0.778^{* * *}\right)$, BOD and temperature $(\mathrm{r}=-0.497)$, TDS and DO $(\mathrm{r}=-0.378)$, TDS and temperature $\left(\mathrm{r}=-0.903^{* *}\right)$, EC and $\mathrm{pH}(\mathrm{r}=-$ $\left.0.903^{* *}\right)$, EC and temperature $\left(\mathrm{r}=-0.960^{* *}\right)$. Similarly, some positive correlations are shown between transparency and hardness $\left(r=0.849^{* *}\right)$, transparency and TDS $(r=0.310)$, transparency and EC $(\mathrm{r}=0.375)$, transparency and $\mathrm{pH}(\mathrm{r}=0.375)$, TDS and hardness $(\mathrm{r}=0.373)$, hardness and EC ( $\mathrm{r}=0.471)$, hardness and $\mathrm{pH}(\mathrm{r}=0.509)$, DO and $\mathrm{pH}(\mathrm{r}=0.146)$, BOD and EC $\left(\mathrm{r}=0.667^{* * *}\right)$, TDS and EC $\left(r=0.929^{* *}\right)$, DO and temperature $(r=0.446)$, and Temperature and $\mathrm{pH}(\mathrm{r}=0.096)$.

\section{Conclusions}

During the monsoon the transparency was low and gradually increased over post-monsoon and pre-monsoon respectively. The temperature was high in the monsoon and gradually decreases during the post and pre-monsoon seasons. The transparency and temperature were within the standard limit. In most cases, electrical conductivity and total dissolved solid were also within the standard limit. During all seasons, at all the points, $\mathrm{pH}$ and DO content were suitable for fisheries, whereas BOD increased slightly during post monsoon. Total hardness and alkalinity were suitable for fisheries during all seasons in all the points. Human growth has significantly altered the environment of many natural water bodies. As a result, the composition of the biota of the water bodies is affected. Rivers are ecologically deteriorated due to unabated discharge of pollutants and heavy fishing pressures. Thus, the protection and improvement of surface water quality of Gowain river regular water quality assessment is necessary that will help the authorities to introduce and implement of appropriate policy guidelines. Such a strategy will conserve and revive the natural resources in the region. 


\section{Acknowledgement}

Sincere gratitude to Ms. Sabiha Akter (MS student) of the Department of ESRM, MBSTU, Bangladesh for kind cooperation throughout the study period. Thanks are also extended to Prof. Dr. P.S. Roy (Centre for Earth, Ocean and Atmospheric Sciences, School of Physics, University of Hyderabad, India) for critically commenting on this manuscript for its improvement for publication.

\section{References}

Ahmed, M.F. and M.M., Rahman (2005). Water supply and sanitation. 2nd Ed, ITN Bangladesh, Centre for water supply and waste management, BUET, Dhaka-1000, Bangladesh.

Choudhury, J.K., Biswas, S.R., Islam, M.S., Rahman, O. and S.N. Uddin (2004). Biodiversity of Ratargul swamp forest, Sylhet. IUCN Bangladesh Country Office, Dhaka, Bangladesh, pp. 4-24.

ECR (Environmental Conservation Rules) (1997). Government of the People's Republic of Bangladesh. Ministry of Environment and Forest, Department of Environment, Dhaka, Bangladesh, pp: 212-214

Ehiagbonare, J.E. and Y.O. Ogunrinde (2010). Physicochemical analysis of fish pond water in Okada and its environments, Nigeria. African Journal of Biotechnology, 9(36): 59225928.

EQS (Environmental Quality Standard) (1997). Government of the People's Republic of Bangladesh. Ministry of Environment and Forest, Department of Environment, Gazette, registered nr.DA-1, Dhaka, Bangladesh.

Hossain M.U., Farzana, S. and M.Y. Mia (2011). Assessment of aquatic environmental parameters in the Louhajang River, Tangail, Bangladesh. Journal of Science and Technology, 1(1): 65-71.

Huq, M.E. (2008). Water resources management in Bangladesh. Anushilan, Chuadanga and Dhaka. pp.24-84.

Huq, S.M.I. and M.D. Alam (2008). A handbook on analysis of soil, plant and water. BACERDU, University of Dhaka, Bangladesh, pp.xii+246.

Islam, M.A., Islam, M.J., Arefin, S., Rashid, A. and Barman, S.K. (2016b). Factors affecting the fisheries biodiversity of Ratargul Swamp Forest of Sylhet district, Bangladesh. IOSR Journal of Environmental Science, Toxicology and Food Technology, 10(1): 60-65.

Islam, M.S., Akter, S., Saha, S.K., Kabir, M.H. and Mamun, S.A. (2017). Fluctuations in water quality at Hakaluki haor of Bangladesh. Bangladesh Journal of Environmental Science, 32: $35-40$.

Islam, M.S., Islam, M.A., Islam, M.J., Kabir, M.H. and Meghla, N.T. (2014). Status of water quality in the Tista river at Kaunia Point and its impact on aquatic environment. Journal of Environmental Science and Natural Resources, 8 (1): 29-33.

Islam, M.S., Kabir, M.H., Sifat, S.A., Meghla, N.T. and Tusher, T.R. (2014). Status of water quality from the Padma river at Bheramara point of Kushtia in Bangladesh. Bangladesh Journal of Environmental Science, 27: 110-115.

Islam, M.S., M.A. Islam, N.A. Sweety, M.A.R. Hossain and M.H. Kabir.2016a. Assessment of aquatic faunal diversity in the Ratargul Swamp Forest at Sylhet in Bangladesh. Journal of Environmental Science and Natural Resources, 9(2): 51-64.

Jonnalagadda, S.B. and Mhere, G. (2001). Water quality of the Odziriver in the eastern highlands of Zimbabwe. Water Research, 35: 2371-2376. 
Joseph, P.V. and Jacob, C. (2010). Physiochemical characteristics of Penan River, A fresh water wetland in Kerala, India. E-Journal of Chemistry, 7(4): 1266-1273.

Meghla, N.T., Islam, M.S., Ali, M.A., Suravi and Sultana, N. (2013). Assessment of physicochemical properties of water from the Turag River in Dhaka City, Bangladesh. International Journal of Current Microbiology Applied Science, 2(5):110-122.

Mobin, M.N., Islam, M.S., Mia, M.Y. and Bakali, B. (2014). Analysis of physicochemical properties of the Turag River water, Tongi, Gazipur in Bangladesh. Journal of Environmental Science and Natural Resources, 7(1): 27-33.

MPCA (2009). Low dissolved oxygen in Water-Causes, Impact on aquatic life-An overview. Water Quality/Impaired Waters 3.24. Minnesota Pollution Control Agency (MPCA).

Rahman M.S. (1992). Water quality management in aquaculture, BRAC Prokashana, Bangladesh, p.84.

Rakiba, K and Ferdusi, Z. (2013). Physicochemical properties of Dhepa river in Dinajpur district of Bangladesh. Journal of Environmental Science and Natural Resources, 6(1): 59-67.

Rehnuma, M., Islam, M.S., Meghla, N.T. and Kabir, M.H. (2016). Investigation of water quality from Bangshi river at Tangail in Bangladesh. Journal of Science and Technology, 6(1 \& 2): 153-160.

Trivedy, R.K. and Goel, P.K. (1984). Chemical and biological methods for water pollution studies. Environmental Publications, KARAD, pp.42-74.

Weber-Scannell, P.K. and Duffy, L.K. (2007). Effects of total dissolved solids on aquatic organisms: A review of literature and recommendation for Salmonid species. American Journal of Environmental Sciences, 3(1): 1-6. 